\title{
IMPACT OF DIFFERENTIATED INSTRUCTION ON ACHIEVEMENT IN TEACHING MATHEMATICS TO LOWER-STAGE GRADES
}

\author{
Sandra Kadum-Bořnjak, MSc; PhD student \\ Department of Educational Sciences, \\ Juraj Dobrila University of Pula (Croatia) \\ e-mail: skadumbo@globalnet.hr \\ Barbara Buršić-Križanac, Graduate Educator \\ Vodnjan Elementary School (Croatia) \\ e-mail: bbkrizanac@gmail.com
}

\begin{abstract}
Summary
This paper presents the results of a research which offers verification of the impact of differentiated instruction on achievement in mathematics in primary school students.

The study was conducted on a sample of 78 third-grade pupils. There were 38 pupils in the control group and 40 pupils in the experimental group.

The results obtained in this study indicate that learning using differentiated instruction, compared against traditional teaching methods, contributed to a significant increase in the overall educational performance. The resulting $t$-value $(t$ $=6.27, d f=76, p<.01)$ indicates that there are significant differences between the actual mean in the experimental group (34.19) and that produced in the control group (27.44).
\end{abstract}

Key words: differentiated instruction, mathematics, teaching, grades, lower-stage grades, achievement

\section{Introduction}

The one-teacher system of teaching is in crisis. One of the reasons relates to the formation of classes where, starting from the assumption that equalizing of pupils regarding their age and relatively similar pre-knowledge, it is considered that it is possible to ensure a relatively great homogeneity of pupils with regard to their abilities, pre-knowledge and capacity, thus achieving their uniform progress. Even though it is widely known that pupils of one class differ considerably regarding their learning tempo, relations towards learning and readiness for learning, when 
planning and carrying out the teaching the system departs from an average pupil ${ }^{1}$. Due to this, the demands imposed on an average pupil are below the capabilities of talented pupils, while usually posing difficulties to below-average pupils. Such approach to teaching and learning leads to considerable (negative) results, both in relation to single students and at the class level. This teaching organisation, learning and teaching, can hardly provide conditions for divergent thinking and create various paths and achievements. (Đorđević, 1981)

The principle of even advancement of all students was justified in a time when basic educational requirements comprised the transfer of a minimum quantity of knowledge and when knowledge borders and opportunities were to a lesser or greater extent determined and defined in advance. In such a situation it was possible to implement goals and tasks along one mean, it was possible to feed the same contents to all pupils in one class, at the same pace and progress. However, when the requirements regarding the educational level have risen and when the right of everyone to education, equal opportunities for all and need to ensure a free and unhindered development to everybody started to be proclaimed - the one-teacher system has shown a string of weaknesses and drawbacks.

These requirements - improvement of the level of education, right of everyone to education, equal opportunities for all, need to ensure a free and unhindered development - have had an impact on the organisation of teaching, steering it more and more towards individual assumptions and the capabilities of students. Didactic and methodical consistency of these requirements mainly concern (1) respect of the motivation and learning pace of the students, (2) social and cultural components linked to the student's environment, and (3) student's inclinations and interests to meet his ambitions, capabilities and creative need.

The modern school, therefore, looks for contemporary strategies of learning and teaching, calls for more efficient approaches and procedures of knowledge acquisition. A special niche is taken by differentiated instruction and, accordingly, by a systematic differentiation of students based on the didactic and methodical principle of individualisation.

Differentiated instruction must, first of all, respect the differences existing among the students. There are countless differences among students, more or less important, with the most important differences be classifiable in the following categories (Đorđević, 1981):

(1) differences in the level of knowledge, skills, experiences and habits;

(2) differences in cognitive capabilities and processes of cognition;

(3) differences in interests;

(4) differences in the pace of learning, motivation for learning and student's development.

1 Duly appreciating the opinions of the psychologists who state that in a group (environment) the average prevail $(50 \%)$ and that there are about $25 \%$ of the above-average and about $25 \%$ of the below average members, Prof. V. Kadum emphasizes that it is more acceptable to divide individuals (students) into (1) those who cannot and want not; (2) those who cannot but want to; (3) those who can but want not and (4) those who can and want. 
These differences between students - as well as some other difference - need to be taken into consideration, and when planning teaching a teacher must learn the contents of differentiating and the implementation of differentiated instruction.

\section{Method}

\section{The subject of research}

The contemporary school today is required to work in an efficient and rational way. The emphasis of modern schooling being put on the acquisition of knowledge and not of ready-made facts, the school is expected in present circumstances to train students to master methods and techniques of independent learning and acquisition of knowledge. One of the solutions is the differentiated mode of learning, a learning form which favours the development of independent learning by animating interest and creative thinking. This is because the "today's theory of mathematics education apodictically claims that the task of mathematics teaching is not to acquire knowledge, but to develop the ability to think and to judge, to train students not to solve this or that problem, but to manage any problem-solving task he may encounter during his existence/life..." (Kadum, 2002, 138).

The goal of this research is to create an opportunity of mitigating the void resulting from the disproportion between theoretical understandings on the concerned phenomenon and the need to solve this phenomenon and the pedagogical positions based in it.

Therefore, the subject of research is learning during the mathematics classes in elementary school lower-stage grades by the implementation of differentiated instruction.

\section{The goal and tasks of research}

In compliance with the formulation of the problem and the subject of research, the goal of this research was to verify the impact of differentiated instruction on achievement in mathematics in primary school students in optimally controlled experimental conditions which were very close to a natural learning situation in the classroom. The research was based on didactic and methodical grounds and the ways to train students for independent work on mathematical contents.

The subject of research and the set goal led to the following task of research:

Determine the differences with regard to the quality of students' knowledge acquired in the conventional, traditional way and knowledge acquired by implementation of the differentiated mode of learning.

The set goal and task of research were the precondition for valid conclusion on (1) the possibilities to implement differentiated instruction in mathematics teaching in elementary school lower-stage grades and (2) the educational effect of 
differentiated mode of learning in mathematics teaching in elementary school lowerstage grades.

\section{Research hypothesis}

Based on the above identified research goal and the set task, the most convenient research hypothesis was the following:

Considering that learning through differentiated instruction has so far proven to be an effective and productive form of learning, it can be assumed that it would bring about a considerable increase in the total educational effect of learning in mathematics teaching in elementary school lower-stage grades.

\section{Instruments}

For the purpose of this research, the following instruments were constructed: (1) initial mathematics test; (2) survey questionnaire on the qualifications of the parents; (3) final mathematics test.

Apart from the above-mentioned instruments, also data on c-values of students at the moment of enrollment in elementary school first grade were used. These were obtained by inspecting school documentation using the (4) protocol on data collection by inspection of school documentation.

Data on c-values was used exclusively to establish pupil's capabilities and to equalize the control and the experimental group with regard to their intellectual maturity.

\section{Research population and sample}

Population, which could potentially be researched, was very large and encompassed all third-grade pupils of all schools in Croatia.

The research was conducted in the Vodnjan Elementary School in Vodnjan and in the Stoja Elementary School in Pula. The sample comprised 78 respondents, third-grade pupils of the above identified schools.

The control group had 38, and the experimental group 40 respondents.

However, it must be emphasized that this sample is not representative of the population and, strictly speaking, the obtained results apply only to this and to such group of respondents. 


\section{Results and discussion}

\section{Sample characteristics}

At the beginning of every school year, all pupils enrolled in the first grade are divided into classes. These classes would continue to ensure a relatively stable group of pupils for the next eight years - the duration of the elementary schooling.

The criteria applied when forming classes can vary. In the elementary schools of Pula and its surrounding areas, classes are formed based on intellectual maturity of children enrolled in the first grade. Every year the pupils of the first grade are tested through a set of tests, their results are then processed to give the $c$-values confirming the individual maturity of single pupils who are to commence schooling. Distribution of students to various classes is carried out on the basis of the obtained $c$-values so that each class receives a relatively equal number of pupils of a certain $c$ value. At the same time, where possible, the wishes of the parents for their child to attend classes of a certain teacher are taken into consideration.

TABLE 1 Individual maturity of pupils at enrolment in the first grade

\begin{tabular}{|c|c|c|c|c|}
\hline \multirow{2}{*}{$c$-value } & \multicolumn{2}{|c|}{ control group } & \multicolumn{2}{|c|}{ experimental group } \\
\hline & $f$ & $\%$ & $f$ & $\%$ \\
\hline 0 & 0 & 0.0 & 1 & 2.5 \\
\hline 1 & 1 & 2.6 & 2 & 5.0 \\
\hline 2 & 3 & 7.9 & 3 & 7.5 \\
\hline 3 & 6 & 15.8 & 3 & 7.5 \\
\hline 4 & 1 & 2.6 & 1 & 2.5 \\
\hline 5 & 6 & 15.8 & 8 & 20.0 \\
\hline 6 & 8 & 21.1 & 8 & 20.0 \\
\hline 7 & 5 & 13.2 & 7 & 17.5 \\
\hline 8 & 4 & 10.5 & 6 & 15.0 \\
\hline 9 & 4 & 10.5 & 1 & 2.5 \\
\hline 10 & 0 & 0.0 & 0 & 0.0 \\
\hline Total: & 38 & 100.0 & 40 & 100.0 \\
\hline $\begin{array}{l}\text { arithmetic mean } \\
\qquad(\bar{X})\end{array}$ & \multicolumn{2}{|c|}{5.526} & \multicolumn{2}{|c|}{5.375} \\
\hline $\begin{array}{c}\text { standard } \\
\text { deviation }(\sigma)\end{array}$ & \multicolumn{2}{|c|}{2.209} & \multicolumn{2}{|c|}{2.132} \\
\hline$t$-value & \multicolumn{4}{|c|}{0.30} \\
\hline
\end{tabular}

Table 1 shows $c$-values of pupils in both the control and experimental group at the moment of their enrolment in the first grade of the elementary school. By comparing the arithmetic means and the corresponding standard deviations, it can be 
noted that the experimental group obtained somewhat better $c$-values $\left(\bar{X}_{E}=5.375\right.$, $\left.\sigma_{E}=2.132 ; \bar{X}_{K}=5.526, \sigma_{K}=2.209\right)$. Nevertheless, the value of the $t$-ratio being 0.30 , the conclusion is that the difference between the arithmetic means is not statistically significant (limiting values of the $t$-test are 1.97 at the level $p=0.05$ and 2.58 at the level $p=0.01$ ). Based on these results it can, therefore, be quite safely said that, regarding the intellectual maturity of the respondents, both group entered the experiment uniformaly $(t=0.30, p>.05)$.

PICTURE 1 Distribution of frequencies of c-value for the control and experimental groups

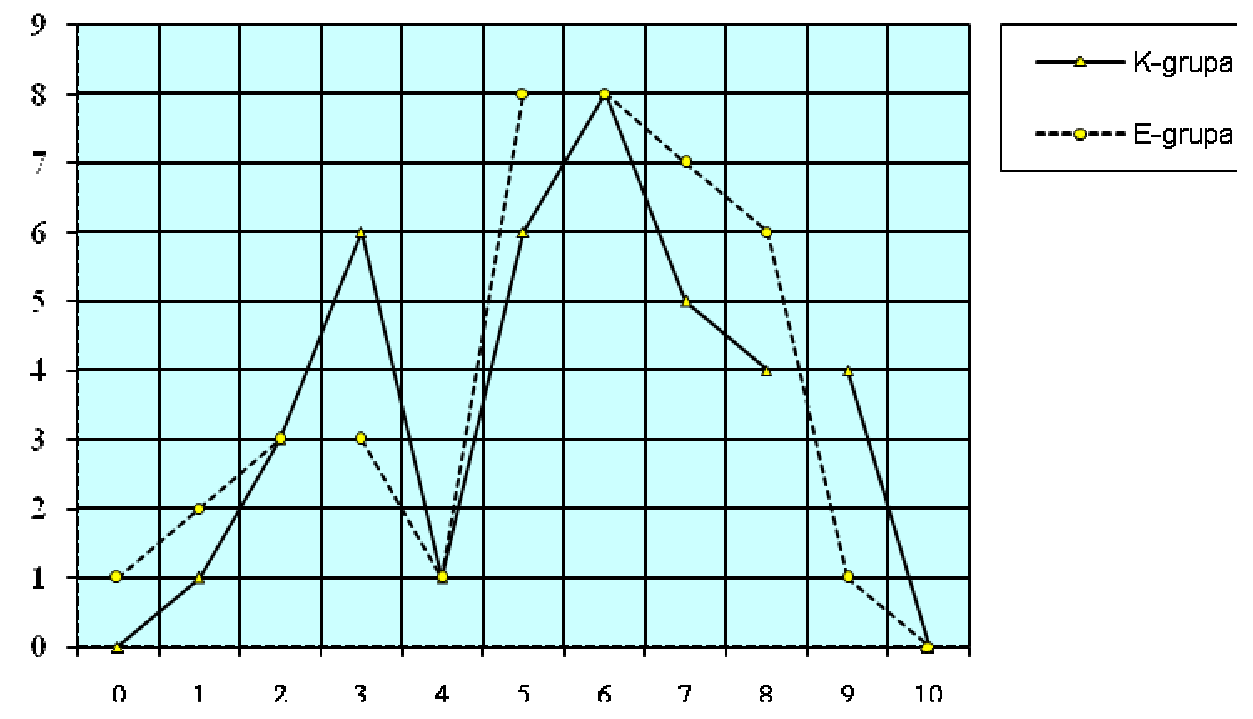

Data on individual maturity of children when enrolling the first grade of elementary school ( $c$-value; Table 1$)$ are graphically chartered by a comparative frequency polygon in Picture 1. It can be seen that the curve graphs match quite well, that they are asymmetric and bimodal (having two peaks).

\section{Level of parents' qualifications}

Data on the level of qualification of the parents of the pupils - respondents in our sample, are shown in Table 2. As can be seen, the "father's level of qualification" is distributed quite well in both control and experimental group. The criterion "mother's level of qualification" is also distributed quite well in both groups. This ensures that this (independent) variable has a similar impact on the experimental factor. 
Consequently, the independent variable level of qualification of parents of pupils in our sample, as a sample characteristic, has the same impact upon both groups.

With reference to the obtained arithmetic means $-\bar{X}=3.03$ in the control group and $\bar{X}=3.20$ in the experimental group - the dominance of the parents' qualification completed secondary school is apparent.

TABLE 2 Level of qualification of parents of pupils in our sample

\begin{tabular}{|c|c|c|c|c|c|c|c|c|c|}
\hline \multirow{2}{*}{ Having... } & \multirow{2}{*}{ parent } & \multicolumn{4}{|c|}{ control group } & \multicolumn{4}{|c|}{ experimental group } \\
\hline & & $f$ & $\%$ & $f$ & $\%$ & $f$ & $\%$ & $f$ & $\%$ \\
\hline \multirow{2}{*}{$\begin{array}{l}\text {...uncompleted } \\
\text { elementary school }\end{array}$} & mother & 0 & 0.0 & \multirow{2}{*}{0} & \multirow{2}{*}{0.0} & 1 & 2.5 & \multirow{2}{*}{1} & \multirow{2}{*}{1.2} \\
\hline & father & 0 & 0.0 & & & 0 & 0.0 & & \\
\hline \multirow{2}{*}{$\begin{array}{l}\text {...completed } \\
\text { elementary school }\end{array}$} & mother & 11 & 28.9 & \multirow{2}{*}{18} & \multirow{2}{*}{23.7} & 5 & 12.5 & \multirow{2}{*}{14} & \multirow{2}{*}{17.5} \\
\hline & father & 7 & 18.4 & & & 9 & 22.5 & & \\
\hline \multirow{2}{*}{$\begin{array}{l}\text {...completed } \\
\text { secondary school }\end{array}$} & mother & 21 & 55.3 & \multirow{2}{*}{45} & \multirow{2}{*}{59.2} & 25 & 62.5 & \multirow{2}{*}{47} & \multirow{2}{*}{58.8} \\
\hline & father & 24 & 63.2 & & & 22 & 55.0 & & \\
\hline \multirow{2}{*}{$\begin{array}{l}\text {...completed 3-year } \\
\text { college }\end{array}$} & mother & 2 & 5.3 & \multirow{2}{*}{6} & \multirow{2}{*}{7.9} & 2 & 5.0 & \multirow{2}{*}{4} & \multirow{2}{*}{5.0} \\
\hline & father & 4 & 10.5 & & & 2 & 5.0 & & \\
\hline \multirow{2}{*}{$\begin{array}{l}\text {...completed } \\
\text { university or higher } \\
\text { education }\end{array}$} & mother & 4 & 10.5 & \multirow[b]{2}{*}{7} & \multirow[b]{2}{*}{9.2} & 7 & 17.5 & \multirow[b]{2}{*}{14} & \multirow[b]{2}{*}{17.5} \\
\hline & father & 3 & 7.9 & & & 7 & 17.5 & & \\
\hline Total & & & & 76 & 100.0 & & & 80 & 100.0 \\
\hline
\end{tabular}

PICTURE 2 Level of qualification of parents of pupils in our sample

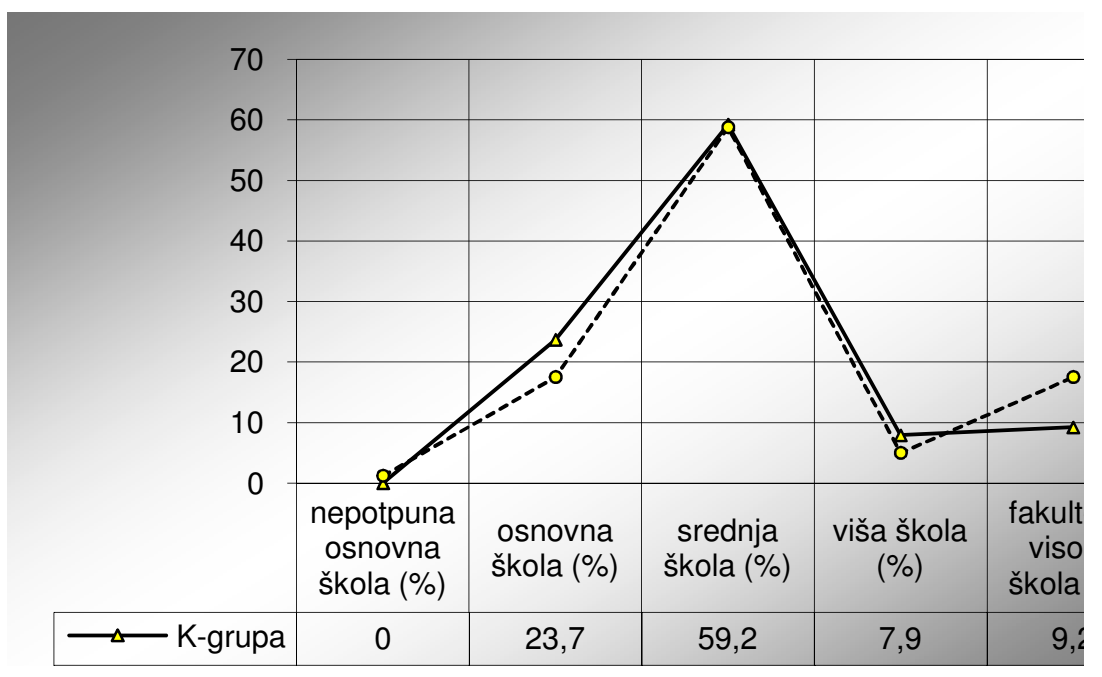


The chi-squares obtained following the statistical treatment of data related to the variable level of qualification of parents of pupils in our sample (Table 2), with Yates correction, are $\chi_{K}^{2}=79.924$ and $\chi_{E}^{2}=79.828, d f=4$, and are almost eight and a half times higher than the limiting value (9.488) at the significance level 0.05 . This implies that that the differences in respondents' answers have not occurred by chance but are statistically significant.

Data displayed in Table 2 are chartered by a comparative frequency polygon in Picture 2. It can be seen that the curve graphs match almost completely, and that the criterion "level of qualification of parents" is distributed quite uniformly in both groups.

\section{Initial test}

The initial test comprised all 78 third-grade pupils of the Vodnjan Elementary School in Vodnjan and the Stoja Elementary School in Pula. The test was administered at the beginning of the school year to establish the mathematics educational level of students after having completed the second grade of elementary school. The test consisted of 38 test items covering the contents prescribed by the curriculum for the first two years of elementary school.

Prior to administering the initial test, we assumed that, considering the previous experiences with regard to pupils' maths grades in lower-stage grades and having inspected the pedagogical documents (students register, class register), the pupils should come to the third grade with a quantum of acquired mathematical knowledge of at least $75 \%$. This is due to the fact that the majority of the pupils - in their first and second grade - obtained excellent or very good grades in mathematics.

Even though the initial test was administered at the beginning of the school year, after the long summer break, when the forgetfulness factor is at its highest, our assumption on the acquisition of mathematical knowledge of at least 75\% was confirmed. The obtained average rate indicates that the success at the test of $82.45 \%$ was achieved (82.5\% in the control group, $82.4 \%$ in the experimental group). Consequently, the initial assumption that pupils come to the third grade with a quantum of mathematical knowledge acquired in the first and second grades of at least $75 \%$ was confirmed by the excellent $82.45 \%$ average result (Table 3 ).

Table 3 in addition shows that a slightly better result was achieved by the respondents belonging to the experimental group ( $\bar{X}=32.95$ compared against the control group $\bar{X}=31.37)$. Nevertheless, the obtained $t$-value (1.48) tells that there is no significantly statistical difference between these two arithmetic means considering that at the level of significance of $5 \%$, the limit of significance is 1.99 with $d f=76$.

The coefficient of variability for the control group being $15.7 \%$, and that for the experimental $13.2 \%$, it can be concluded that the results achieved at the initial test vary slightly more within the control group. 
TABLE 3 Results of the initial test

\begin{tabular}{|c|c|c|c|c|c|c|c|c|c|}
\hline \multirow[b]{2}{*}{ 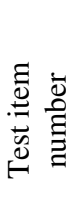 } & \multicolumn{2}{|c|}{ K-group } & \multicolumn{2}{|c|}{ E-group } & \multirow[b]{2}{*}{ 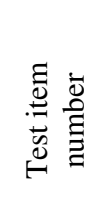 } & \multicolumn{2}{|c|}{ K-group } & \multicolumn{2}{|c|}{ E-group } \\
\hline & 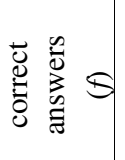 & 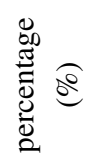 & 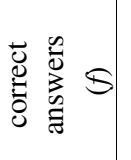 & 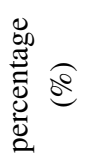 & & 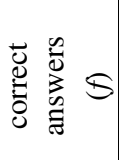 & 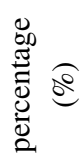 & 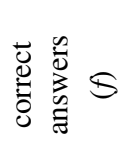 & 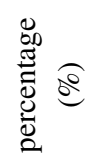 \\
\hline 1. & 33 & 86.8 & 36 & 90.0 & 20. & 35 & 92.1 & 38 & 95.0 \\
\hline 2. & 25 & 65.8 & 37 & 92.5 & 21. & 37 & 97.4 & 38 & 95.0 \\
\hline 3. & 33 & 86.8 & 36 & 90.0 & 22. & 37 & 97.4 & 36 & 90.0 \\
\hline 4. & 38 & 100.0 & 39 & 97.5 & 23. & 38 & 100.0 & 34 & 85.0 \\
\hline 5. & 36 & 94.7 & 34 & 85.0 & 24. & 34 & 89.5 & 36 & 90.0 \\
\hline 6. & 33 & 86.8 & 38 & 95.0 & 25. & 34 & 89.5 & 33 & 82.5 \\
\hline 7. & 34 & 89.5 & 34 & 85.0 & 26. & 32 & 84.2 & 31 & 77.5 \\
\hline 8. & 36 & 94.7 & 40 & 100.0 & 27. & 33 & 86.8 & 35 & 87.5 \\
\hline 9. & 35 & 92.1 & 37 & 92.5 & 28. & 30 & 78.9 & 24 & 60.0 \\
\hline 10. & 32 & 84.2 & 34 & 85.0 & 29. & 31 & 81.6 & 34 & 85.0 \\
\hline 11. & 33 & 86.8 & 26 & 65.0 & 30. & 29 & 76.3 & 27 & 67.5 \\
\hline 12. & 32 & 84.2 & 35 & 87.5 & 31. & 35 & 92.1 & 34 & 85.0 \\
\hline 13. & 24 & 63.2 & 25 & 62.5 & 32. & 32 & 84.2 & 33 & 82.5 \\
\hline 14. & 28 & 73.7 & 24 & 60.0 & 33. & 26 & 68.4 & 32 & 80.0 \\
\hline 15. & 22 & 57.9 & 26 & 65.0 & 34. & 29 & 76.3 & 29 & 72.5 \\
\hline 16. & 23 & 60.5 & 30 & 75.0 & 35. & 34 & 89.5 & 32 & 80.0 \\
\hline 17. & 20 & 52.6 & 24 & 60.0 & 36. & 26 & 68.4 & 34 & 85.0 \\
\hline 18. & 38 & 100.0 & 38 & 95.0 & 37. & 25 & 65.8 & 34 & 85.0 \\
\hline \multirow[t]{6}{*}{19.} & 37 & 97.4 & 35 & 87.5 & 38. & 23 & 60.5 & 30 & 75.0 \\
\hline & & & & & $\mathrm{N}$ & \multicolumn{2}{|c|}{38} & \multicolumn{2}{|c|}{40} \\
\hline & & & & & 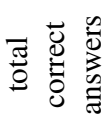 & \multicolumn{2}{|c|}{1192} & \multicolumn{2}{|c|}{1252} \\
\hline & & & & & $\bar{X}$ & 31.37 & $\begin{array}{c}82.5 \\
\%\end{array}$ & 32.95 & $82.4 \%$ \\
\hline & & & & & $\sigma$ & \multicolumn{2}{|c|}{4.94} & \multicolumn{2}{|c|}{4.34} \\
\hline & & & & & 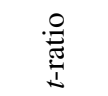 & \multicolumn{4}{|c|}{1.48} \\
\hline
\end{tabular}


Data resulting from Table 3 are chartered in Picture 3. It can easily be discerned that these data match quite well, which points to equality of results at the initial test.

Both Picture 3 and Table 3 indicate that in the control group ten test items were solved at a level lower than the presumed success rate $(75 \%)$, while in the experimental group there were only 8 such test items (out of 38 test items).

PICTURE 3 Matching of results at the initial test

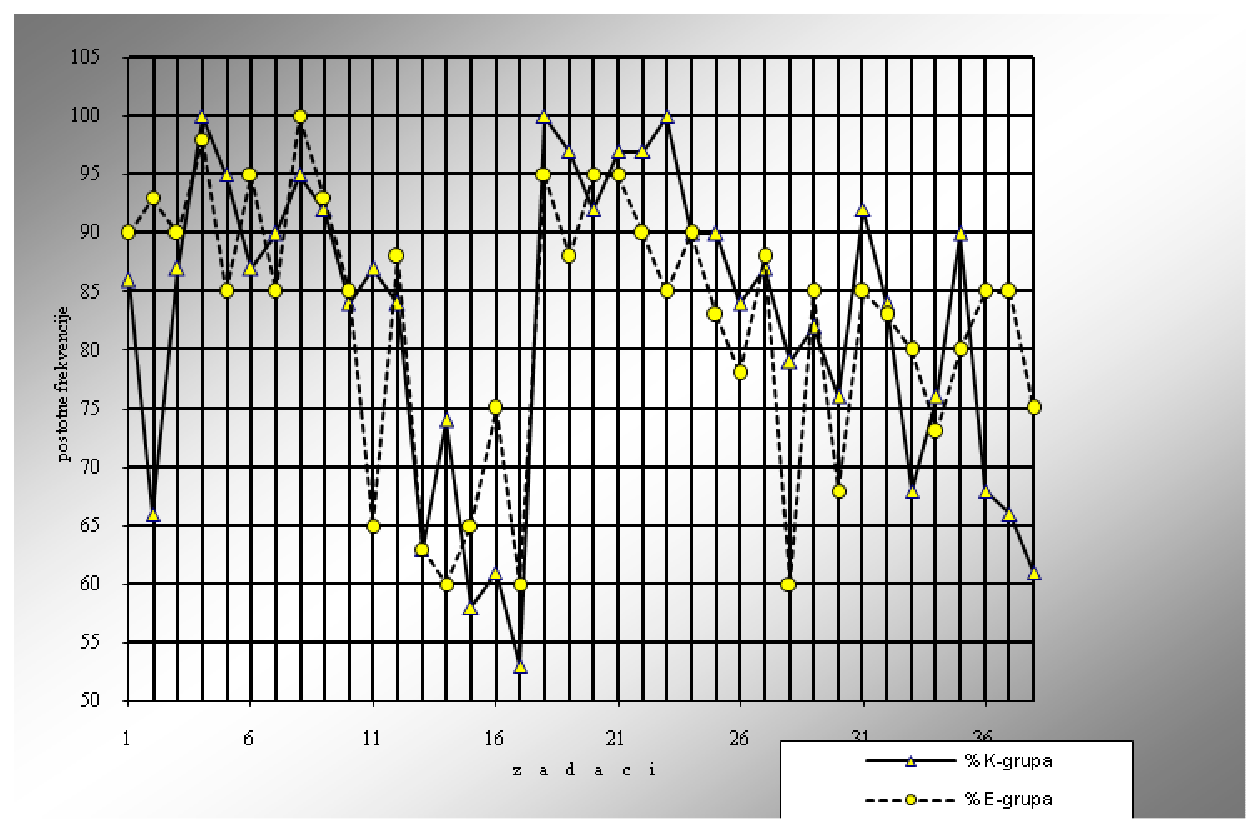

On the basis of the presented initial test results, it can be concluded that the groups - experimental and control - entered the experiment at the same level and, accordingly, the conditions to organise the experiment by application of parallel equivalent groups were met.

\section{Final test}

Following the completion of the initial test and inspection of pedagogical documents, a differentiated work programme was created with regard to teaching mathematics to third grade pupils. This programme was implemented in the experimental group, while the pupils in the control group continued to work in the conventional, traditional way.

While creating the differentiated work programme we paid special attention to the fact that the steering of instruction towards absolute individualisation is limited as it hides risks to neglect what is important, what should be common to all students - certain standards of knowledge and behaviour. In fact, individualisation 
of instruction to an extreme stage is neither necessary nor appropriate to the endeavours of contemporary education. Experience has shown that no extreme form of individualisation (Dalton Plan, teaching by free groups etc.) had any permanent effect. Keeping this in mind, Roth (1970) pointed to the very important fact that there is common fundamental knowledge that needs to be acquired, for life essential reasons, by all individuals in development, which enables a wide field of acquisition of further experience when existing and possible interests of pupils are in question.

TABLE 4 Results of the final test

\begin{tabular}{|c|c|c|c|c|}
\hline \multirow[b]{2}{*}{$\begin{array}{l}\text { Test item } \\
\text { number }\end{array}$} & \multicolumn{2}{|c|}{ K-group } & \multicolumn{2}{|c|}{ E-group } \\
\hline & $\begin{array}{c}\text { correct } \\
\text { answers } \\
(f)\end{array}$ & $\begin{array}{c}\text { percentage } \\
(\%)\end{array}$ & $\begin{array}{c}\text { correct } \\
\text { answers } \\
(f)\end{array}$ & $\begin{array}{c}\text { percentage } \\
(\%)\end{array}$ \\
\hline 1. & 30 & 75.0 & 38 & 95.0 \\
\hline 2. & 23 & 57.5 & 38 & 95.0 \\
\hline 3. & 37 & 92.5 & 40 & 100.0 \\
\hline 4. & 37 & 92.5 & 40 & 100.0 \\
\hline 5. & 35 & 87.5 & 40 & 100.0 \\
\hline 6. & 24 & 60.0 & 40 & 100.0 \\
\hline 7. & 33 & 82.5 & 40 & 100.0 \\
\hline 8. & 31 & 77.5 & 40 & 100.0 \\
\hline 9. & 27 & 67.5 & 33 & 82.5 \\
\hline 10. & 23 & 57.5 & 35 & 87.5 \\
\hline 11. & 30 & 75.0 & 36 & 90.0 \\
\hline 12. & 29 & 72.5 & 35 & 87.5 \\
\hline 13. & 19 & 47.5 & 34 & 85.0 \\
\hline 14. & 22 & 55.0 & 21 & 52.5 \\
\hline 15. & 15 & 37.5 & 19 & 47.5 \\
\hline 16. & 14 & 35.0 & 18 & 45.0 \\
\hline $\mathrm{N}$ & \multicolumn{2}{|c|}{38} & \multicolumn{2}{|c|}{40} \\
\hline $\begin{array}{c}\text { Total } \\
\text { correct } \\
\text { answers }\end{array}$ & \multicolumn{2}{|c|}{439} & \multicolumn{2}{|c|}{547} \\
\hline $\bar{X}$ & 27.44 & $72.2 \%$ & 34.19 & $85.5 \%$ \\
\hline$\sigma$ & \multicolumn{2}{|c|}{4.64} & \multicolumn{2}{|c|}{4.75} \\
\hline$t$-ratio & \multicolumn{4}{|c|}{6.27} \\
\hline
\end{tabular}

Naturally, we have accepted the points of view by Hartief (1972), who emphasized that the organisation of learning must be considered in an organisational 
and sociological sense as a "social system or social creation not only from the organisational aspects, but as a unit of all planned, unplanned and unforeseen social processes in progress within the system or in relation to other, neighbouring systems" (Hartief, 1972; according to: Đorđević, 1981, 120). This means that the study of various forms of differentiation also needs to include their relevance regarding attitudes, aspirations and models of interaction between individuals and groups who take place in the learning process.

Differentiated form of work with students of the experimental group commenced at the beginning of October and lasted until the spring break, i.e. until the beginning of April. The experimental programme thus lasted over six months. At the completion of the programme, a final test was administered contemporarily to both control and experimental group.

Unlike the initial, test which consisted of 38 test items, the final test consisted of sixteen test items.

The results achieved at the final test are shown in Table 4.

PICTURE 4 Results achieved at the final test

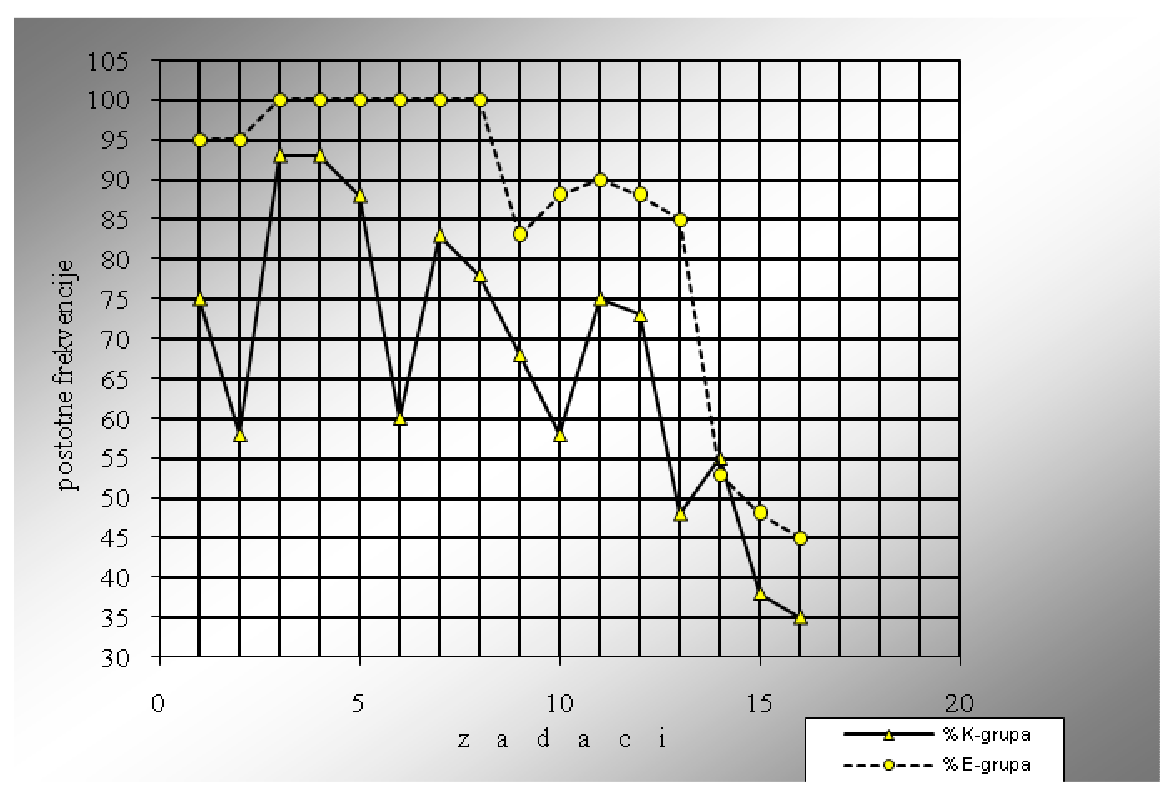

Detailed data on the quantitative indicators of distribution of results achieved at the test per group are chartered by a comparative frequency polygon (Picture 4) and indicate the level of acquisition of the third-grade mathematics contents in the control and experimental group.

Regardless that in the two measurements - initial and final - two tests were applied, different in content but equal in design and structure of test items and related in purpose, the experimental group achieved better results in the final test (Table 4). 
Table 4 makes it evident that the experimental group $(\bar{X}=34.19)$ obtained considerably better results compared to the control group $(\bar{X}=27.44)$. In percentages, the solvability rate of the final test in experimental group was $85.5 \%$ and in the control group the rate was $72.2 \%$.

The obtained $t$-value (6.27) is almost three and a half times bigger than the limit of significance (1.99) at the level of $5 \%$ with $d f=76$, which indicates that there are statistically significant differences between the arithmetic mean obtained in the experimental group (34.19) and that obtained in the control group (27.44), $(t=6.27$; $p<0.05 ; d f=76$ ).

Since the variability coefficient for the control group is $16.9 \%$, and that for the experimental group $13.9 \%$, the results at the final test varied more in the control group.

Picture 4 clearly shows that the whole data graph (percentage frequency polygon) of the experimental group (except for test item 14) above the data graph of the control group.

The success of the experimental group is the result of an effective implementation of differentiated mode of learning on the knowledge acquisition plane, which enabled a better educational effect (success) achieved in the lowerstage grades.

Keeping in mind that the knowledge and other relevant factors at the beginning of the experiment were equivalent, we consider that the difference arose under the influence of the experimental factor, i.e. by application of the differentiated mode of learning of a part of the teaching content scheduled for the third grade of the elementary school. This has, in fact, confirmed our hypothesis.

Accordingly, within the framework of our experiment, learning by application of differentiated instruction has shown considerable advantage over the conventional mode of teaching at the general level of knowledge, i.e. educational impact in the teaching of mathematics to lower-stage grades of the elementary school.

\section{Conclusion}

The organisation and implementation of the pedagogical experiment on the impact of differentiated instruction in the teaching of mathematics to elementary school lower-stage grades departed from theoretical and practical understandings and needs of the pedagogical practice. The research has, therefore, brought differentiated instruction into spotlight as one of the forms of learning and teaching but also of increasing the efficiency of instruction.

The paper is based on the analysis of a theoretical approach of differentiated instruction. The conclusion was that the efficiency of mathematics teaching can be affirmed if differentiated instruction is implemented. This form of learning ensures the optimum climate to acquire quality knowledge based on, among other things, a greater mental activity of students and to discern essential links and relations between the studied mathematical contents. 
Pedagogical justification of the experimental verification of the impact of learning of mathematics in lower-stage grades by implementation of differentiation can be found in the understanding that such mode of instruction characterises the novelty and difficulty of an initial learning stage, goal direction, high level of student's motivation and effort to solve the set tasks with more success.

Students of the experimental group showed excellent activity, comprehensive approach to mathematics content, rationality, creativity and criticalness. They were trained to immerse independently in mathematical contents, to research and discover relevant facts and laws of mathematics.

The subject of this research was the experimental verification of the impact of learning of mathematics in lower-stage grades by implementation of differentiation. Modern didactic and methodical theory advocates the training of students to accept and adapt to procedures and modes which will enable them access to the necessary data.

The verification of the impact of the experimental factor was carried out through the experiment involving parallel, approximately equivalent groups. We opted, therefore, for a rather reliable methodological procedure in order to obtain the necessary data on the level of correctness of the formulated hypothesis.

A number of measuring instruments were applied, all of them featuring favourable metric characteristics. Measuring instruments represent a reliable data source, which created a firm base to bring the final judgment on the accuracy of the formulated hypotheses and to reach relevant conclusions.

The initial measuring confirmed that both groups entered the experiment on an equivalent level in all relevant features, which created the conditions for justifiable expectation that the experimental factors would be the cause and source of the presumed verified variants.

\section{Bibliography} knjiga.

ĐORĐEVIĆ, J. (1981), Savremena nastava - organizacija i oblici. Beograd: Naučna

KADUM, V. - KADUM-BOŠNJAK, S. (2006), Nastava različitih razina zahtjevnost. Pula: Metodički obzori, časopis za odgojno-obrazovnu teoriju i praksu, vol. 1(2006)1; str. 26-36.

KADUM, V. (2005), Učenje rješavanjem problemskih zadataka u nastavi (matematike). Pula: IGSA

KADUM, V. (1997), Zaostajanje učenika u matematici - uzroci i mogućnosti otklanjanja. Pula: Pedagoški fakultet

LAVRNJA, I. (1998), Poglavlja iz didaktike. Rijeka: Pedagoški fakultet.

MARKOVAC, J. (1966), Nastava i individualne razlike učenika. Zagreb: Školska knjiga. udžbenika.

MUŽIĆ, V. (1968), Metodologija pedagoškog istraživanja. Sarajevo: Zavod za izdavanje

POTKONJAK, N. i ŠIMLEŠA, P. /ur./, (1989), Pedagoška enciklopedija. Zagreb: Školska knjiga 
VUJEVIĆ, M. (2006), Uvođenje u znanstveni rad u području društvenih znanosti. Zagreb: Školska knjiga.

Metodički obzori 7(2012)2

Izvorni znanstveni rad

UDK: 373.1:51]:373.32

Primljeno: 23.12. 2010.

\section{UTJECAJ DIFERENCIRANE NASTAVE NA POSTIGNUĆE U NASTAVI MATEMATIKE NIŽIH RAZREDA OSNOVNE ŠKOLE}

Mr. sc. Sandra Kadum-Bošnjak, Odjel za odgojne i obrazovne znanosti, Sveučilište Jurja Dobrile u Puli e-mail: skadumbo@globalnet.hr

Barbara Buršić-Križanac, diplomantica Osnovna škola Vodnjan - Scuola elementare Dignano e-mail: bbkrizanac@gmail.com

S a ž et $\boldsymbol{a} k$

U radu se izlažu rezultati istraživanja kojega je cilj bio verifikacija utjecaja diferencirane nastave na postignuće u nastavi matematike nižih razreda osnovne škole.

Istraživanje je provedeno na uzorku od 78 ispitanika, učenika trećih razreda osnovne škole. U kontrolnoj je grupi bilo 38, a u eksperimentalnoj 40 ispitanika.

Rezultati dobiveni u ovome istraživanju kazuju da je učenje primjenom diferencirane nastave, u odnosu na tradicionalnu nastavu, doprinijelo značajnom povećanju ukupnog obrazovnog učinka. Dobivena $t$-vrijednost $(t=6.27 ; d f=76$; $p<.01)$ kazuje da postoje statistički značajne razlike između ostvarenih aritmetičkih sredina u eksperimentalnoj (34.19) i one polučene u kontrolnoj grupi (27.44).

Ključne riječi: diferencirana nastava, matematika, nastava, niži razredi, osnovna škola, postignuće 